\title{
An Evaluation of the National Greening Program Implementation in Simala, Cebu Philippines Utilizing ABCD Model
}

\author{
Rongie C. Abella \\ College of Teacher Education, University of Cebu - Main Campus, \\ Cebu City, Philippines \\ Jezyl C. Cutamora, PhD \\ College of Nursing, Cebu Normal University, Cebu City, Philippines
}

Doi:10.19044/esj.2019.v15n10p168 URL:http://dx.doi.org/10.19044/esj.2019.v15n10p168

\begin{abstract}
This descriptive-evaluative study is an evaluation of the effectiveness of the implementation of the National Greening Program in Simala National High School, a secondary public school in Cebu, Philippines utilizing the ABCD model. It identified the congruences and discrepancies of the intents and actualities of the following components: A - the participants, B - programs and operations, $\mathrm{C}$ - effects, and D - the social impact. It was revealed that for component A, $63.83 \%$ of the target participants cooperated in the program activities. Component $\mathrm{B}$ evaluation showed that most of the objectives to operate the program based on DepEd Order No. 5, s. 2014 were achieved with just minor discrepancies. For component $\mathrm{C}$, the following themes encapsulate the effects of the program to the participants which are "points for the effort", "complied as required", "green advocates", and "environmental champions". While the themes "disaster mitigation" and "fighting malnutrition" as the program's social impacts assessed in component D were attained. Thus, the school effectively implemented the program in one school year. Planning ahead the schedule of activities through proper channeling of information and strictly requiring all target participants to attend are advisable. Coordinating with the proper office in setting up the seed bank facilities and forging more partnerships with the concerned public and private agencies are recommended to further minimize the gap between the intents and actualities.
\end{abstract}

Keywords: National Greening Program, ABCD Model, evaluative design, program evaluation, Asia 


\section{Introduction}

The devastating effects of calamities and scarcity of resources caused by deforestation has prompted the Philippine government to launch a program addressing these problems which have affected the lives of millions of Filipinos (Lachica, 2014; Sarker \& Rodrigo, 2014). Former President Benigno Aquino III signed Executive Order (EO) No. 26 on February 2011 which established the National Greening Program (Aquino \& Daquio, 2014). This is in line with the priority programs of the government namely poverty reduction, resource conservation and protection, productivity enhancement, and climate change mitigation and adaptation (Balangue, 2016; Luna, 2016). The National Greening Program (NGP) aims to accomplish growing 1.5 billion trees to reforest about 1.5 million hectares in the entire country at the span of six years which is from 2011 to 2016 (Israel, 2016; Aquino \& Daquio, 2014).

Executive Order No. 23 series 2011 which established the Department of Agriculture (DA) - Department of Agrarian Reform (DAR) - Department of Environment and Natural Resources (DENR) Convergence Initiative has a mandate to forge partnership with the Department of Education (DepEd) and other government agencies in the NGP implementation (Balangue, 2016). EO No. 26, s. 2011 specified the roles of various agencies to ensure the efficient accomplishment of the expected deliverable in the next six years. As stipulated in Section 5.2 of the same EO, DepEd's responsibilities shall include but not limited to the following: students mobilization, nursery establishment, seedling production, and tree planting, information, education, and communication, provision of extension services, and monitoring and evaluation. In line with these responsibilities, the Department of Education then issued DepEd Memorandum No. 58, s. 2011 entitled "Creating the Task Force on National Greening Program".

However, years after the creation of the task force composed of DepEd pesonnel, NGP implementation has not been thoroughly enforced throughout the department. Thus on February 2014, the department issued the guidelines to concretize directions and define key components in the implementation of the program. DepEd Order No. 5, s. 2014 contained the implementing guidelines on the integration of 'gulayan sa paaralan', solid waste management, and tree planting under NGP. The memorandum stated that NGP shall be implemented in all public elementary and secondary schools nationwide in which the program will be integrated in the School Improvement Plan (SIP). It was also emphasized that the teachers' participation of this program will be included as one of the indicators in their annual performance evaluation. Narrative reports of this program with geotagged pictures are even required to those who seek promotions for teachers, school heads, and district supervisors. Furthermore, consolidated Tree and Vegetable Growing quarterly reports will be part of Grade 6 and 10 students 
graduation and completion requirements respectively. Thus, each school is required to submit regular reports regarding the status of their implementation of NGP.

Simala National High School, as one of the public secondary schools in Cebu, Philippines with a population of more than a thousand students, has been implementing NGP based from the implementing guidelines issued by DepEd in 2014. A school NGP coordinator has been appointed to oversee the program implementation and report to the authorities the implementation process. Since one of the responsibilities of DepEd in this program is monitoring and evaluation (DO 5,s. 2014), it is highly desired to conduct this study which evaluate if the implementation of NGP has been effective or not. This is to further identify the best practices to be sustained and areas of opportunities to be improved. Chen and Chen (2005) emphasized that feedback is what program evaluation is all about. Especially now that the Philippine government has decided to extend and expand the program until 2028 through Executive Order No. 193, a set of standards and discipline should be embarked on a system that is growing (Akomolafe \& Adesua, 2019). Delving at the grassroots of program implementer will yield more concrete findings and deeper analysis better than by just looking at the aggregate numbers and statistics presented by the national agencies.

ABCD evaluation model developed by Jesus A. Ochave is utilized to fully evaluate the entirety of the program in its one year of implementation. The model can evaluate effectively programs with longer implementation duration as it covers various components (Mehrafsha, 2011). It explores the program outcomes of NGP which may have both short-term and long-term manifestations (Chen \& Chen, 2005).

The model has four components which are A - the participants, B programs and operations, C - effects, and D - the social impact (Mangarun, 2014). These four major components have its respective "intents" and "actualities" dimensions. The gaps of these dimensions will explain the quality of the program effects and impact (Nava et al, 2007).

\section{Objectives of the Study}

The main purpose of this study is to evaluate the effectiveness of the implementation of the National Greening Program in Simala National High School for the school year 2016-2017 using the ABCD evaluation model. It aims to identify the congruences and discrepancies of the intents and actualities of the following components: A - the participants, B - programs and operations, $\mathrm{C}$ - effects, and D - the social impact. The gaps of these dimensions are the bases of assessing the program's effectiveness. 


\section{Literature Review}

On February 24, 2011, Former President Benigno S. Aquino III signed Executive Order (EO) No. 26 to order and declare the implementation of a National Greening Program (NGP) as a government priority (Lachica, 2014). Its coverage entails to plant 1.5 billion trees covering about 1.5 million hectares for a six year implementation period from 2011 to 2016 . One of the strategies to ensure its successful implementation is to require all students identified by DepEd and CHED and all government employees to plant at least ten seedlings per year. Private sectors and civil groups are also encouraged to participate in the program (Aquino \& Daquio, 2014). The responsibilities of its partner agencies are also discussed. Particularly the Department of Education's responsibilities include but not limited to the following: student mobilization, nursery establishment, seedling production, and tree planting, information, education, and communication, provision of extension services, and monitoring and evaluation.

On February 07, 2014, the Department of Education issued DepEd Order (DO) No. 5, s. 2014 entitled the implementing guidelines on the integration of 'gulayan sa paaralan', solid waste management, and tree planting under the National Greening Program. It contained the provision that all public elementary and secondary schools nationwide shall implement NGP which include the students, teaching and non-teaching personnel. It said that NGP should be integrated in the school improvement plan and in other cocurricular activities. It will be included as one of the performance evaluation indicators of students and teachers. Specifically the objectives of DepEd to successfully implement NGP cover the involvement of students, teaching and non-teaching personnel in the tree growing activities, the establishment of vegetable gardens to serve as a ready source of vegetables for supplementary feeding program complemented with nurseries or seed banks to sustain seed requirement for different planting cycles, the development of values among learners by integrating curricula concepts in planting and eating vegetables, waste management and environmental protection, strengthening the coordination with other government and non-government agencies relative to the program and lastly conducting monitoring and evaluation. The evaluation part is the focus of this study.

A related study by Zubair \& Garforth (2006) identified the role of farmer's perceptions and attitudes to farm level tree planting which is a program that aimed to address the degradation of forest in Pakistan. It was revealed that farmers perceived farm forestry as economically beneficial and environmentally friendly. The perception of its positive impacts outweighed its negative side. It was recommended that by addressing the factors underlying the reasons of not planting trees then farm forestry programs are more likely to be successful. This related study revealed that perception of the 
stakeholders plays an important role in assessing whether the program has been achieving its implementation goals.

Another study by Garen et al (2009) evaluated the farmer's experiences in planting native trees in rural Panama as part of a reforestation program. Environmental and economic benefits were the main reasons for the farmers' desire to plant more trees. The on-going technical support for this program boosted the widespread interest in planting native species (Garen et al, 2009). This study is an example of an evaluation for government programs that target to reforest huge areas. It aimed to identify lessons that can serve as guide for future tree planting efforts. Similarly, this evaluative study of NGP aims to apply an evaluation approach to systematically assess the planning, implementation, and effectiveness to its stakeholders as bases for its enhancement (Chen \& Chen 2005).

\section{Methodology}

A descriptive-evaluative design was employed in this study. Matching the actual happenings of the program implementation referred as "actualities" with the objectives of National Greening Program referred as "intents" made this study evaluative.

\section{Research Locale and Respondents}

This study was conducted in Simala National High School and tree planting sites within the barangay of Simala, Cebu, Philippines. The barangay has coastal and rural areas in which its main livelihoods are fishing and farming. Different set of respondents and methods were considered in every component of the program that was assessed. Since interviews were done to assess the personal effects and social impact of the program to the informants, purposive sampling was utilized. To determine the number of informants needed in the study, data saturation was primarily considered. Merriam and Tisdell (2016) pointed out that saturation occurs when continued data collection produces no new information or insights into the phenomenon being studied. In this study, ten students and ten teachers who actively participated NGP had provided enough data for the personal effects. Eight residents living near the tree planting site and ten parents of the identified undernourished students subjected to the feeding program were interviewed before the data reached the saturation point.

\section{Data Collection and Analysis}

Analysis of related documents and discussions with the school NGP coordinator were the sources of data to answer component A and B of the evaluation model. The documents that served as sources of data were the executive orders, DepEd orders, monthly reports of teachers and the quarterly 
and year-end reports of the School NGP Coordinator. Qualitative data were primarily utilized which were gathered from interviews and discussion with key informants such as the teachers, parents, residents and students to answer component $\mathrm{C}$ and $\mathrm{D}$. One-on-one interviews among the key informants were done to determine NGP's personal effects to their end. Interviews with open ended questions were undertaken also to the immediate residents surrounding the tree planting sites and parents of the undernourished students who were recipients of the feeding program. Assent form and informed consent form were signed by key informants before the interviews were undertaken. Collaizi method of data analysis was utilized which provide support in processes such as extracting significant statements, organizing and analyzing narrative data set (Shosha, 2012). The researcher then seek verification through going back to the participants and confirm whether the themes generated capture their experiences (Morrow et al, 2015).

ABCD evaluation model was used where the congruences and discrepancies between the intents and actualities were identified. The bigger the discrepancy or the gap, the less positive is the evaluation (Mehrafsha, 2011). These gaps are the indicators on deciding if the program has been effective or not. Summary Matrix of Information was utilized in presenting the data where it is composed of columns that include the intents, actualities, and congruences or discrepancies of a particular component. Analysis was done based on the congruences and discrepancies of some components.

\section{Results and Discussion}

Table 1 presents the intents and actualities as evaluated in Component A of the model.

Table 1. Component A - The participants

\begin{tabular}{|c|c|c|}
\hline Intents & Actualities & Congruences / Discrepancies \\
\hline $\begin{array}{l}\text { 1. All students from Grade } 7 \text { to } \\
\text { Grade } 11 \text { shall plant at least ten } \\
\text { trees per year. }\end{array}$ & $\begin{array}{l}\text { All Grade } 11 \text { and } 10 \text { students } \\
\text { were able to plant at least ten } \\
\text { trees. Only the pilot sections } \\
\text { from Grade } 7,8 \text {, and } 9 \text { were able } \\
\text { to participate. } \\
\text { Actual: } 714 \text { students }(63.02 \%)\end{array}$ & $\begin{array}{l}\text { Only } 13 \text { out of the } 22 \text { class } \\
\text { sections had participated. } \\
\text { Among } \\
1,133 \text { students, } 714 \text { or } 63.02 \% \\
\text { of the students were able to join } \\
\text { the tree planting activity. } \\
\text { Gap: } 419 \text { students }(36.98 \%)\end{array}$ \\
\hline $\begin{array}{l}\text { 2. All teaching and non-teaching } \\
\text { personnel shall plant at least ten } \\
\text { trees per year. }\end{array}$ & $\begin{array}{l}\text { All the teachers with the school } \\
\text { head were able to join at least } \\
\text { one tree planting activity. The } \\
\text { two non-teaching personnel of } \\
\text { the school did not get involve of } \\
\text { the activity. } \\
\text { Actual: } 29 \text { school personnel } \\
(93.55 \%)\end{array}$ & $\begin{array}{l}\text { All } 28 \text { teachers and } 1 \text { school } \\
\text { head had participated at least } \\
\text { one activity. The } 2 \text { non-teaching } \\
\text { personnel have not joined at } \\
\text { least one tree planting schedule } \\
\text { as required. } \\
\text { Gap: } 2 \text { non-teaching personnel } \\
(6.45 \%)\end{array}$ \\
\hline $\begin{array}{l}\text { Total Target of Participants: } 1 \text {, } \\
164\end{array}$ & $\begin{array}{l}\text { Actual Participants: } 743(63.83 \\
\%)\end{array}$ & Gap: $421(36.17 \%)$ \\
\hline
\end{tabular}


Intent 1. The Department of Education has been a major partner in the NGP implementation because of the huge number of participants it can offer. All Grade 11 and 10 students were able to plant the minimum requirement of ten trees. However, not all the students of the school were able to join the tree planting activity which was usually conducted on the last Saturday of every month based on the Division Memorandum. Only the pilot sections from Grade 7,8, and 9 were able to participate. The usual arrangement of the school for the tree planting activity was to bring only 2 or 3 classes in every schedule so that the number of students involved was just manageable by the attending teachers. A smaller number of students was highly preferred. Most of the time, the tree planting site was in the seashore since the school has been advocating in the propagation of mangroves along the shoreline of the barangay. The school believes that local mangrove planting produces important ecological and economic benefits (Walters, 2000).

The failure of involving some of the students in the tree planting activity could be attributed to the school's non-compliance of the once a month tree planting schedule. The school was only able to hold six out of the ten tree planting schedules for the school year 2016-2017. Thus some students were not given chances to join at least one tree planting activity. The classes or sections to be brought in every schedule should then be identified ahead of time in order to give a heads up to the students and their respective advisers when will be their turn to plant trees.

The school head and teachers should strive hard to conduct the activity once in a month to involve all the students in complying with the ten trees requirement. The participation of students in environmental protection and preservation is highly encouraged through environmental education. School children are given the obligation to actively participate in activities advocating the environment because they are highly vulnerable to the devastating effects of degrading surroundings (Toili, 2007). Secondary school students in particular are highly motivated to take action in preventing the destruction since they better understand what may happen if the environment will be destroyed (UNEP, 1992).

Intent 2. All the teachers were required to attend every schedule of the tree planting activity. However due to its schedule which usually happened on Saturday morning, some teachers were not able to attend on some schedule due to various reasons such as graduate studies, prenatal or their child's checkup, or family events. Teachers who mostly skipped the activity should be made realized by the school head that their attendance of this activity will be part of the promotion requirements. The two non-teaching personnel who are the administrative assistants of the school were not required by the school head to join the activity. Hence, they failed to comply the ten trees requirement that may be needed once they seek promotion. The school head then needs to 
include the non-teaching personnel on the activities as they are part of the identified participants in this program as stated in the DepEd order.

\section{Table 2. Component B - Programs and Operations}

Intents
1. Involve the students,
teachers, and non-
teaching personnel in the
tree growing activity.

Target: 11, 640 trees grown gardens to serve as food basket and ready source of vegetables to sustain supplementary feeding program.

Actualities

A monthly tree growing activity were conducted which usually happened every last Saturday of the month. However only 6 out of the 10 scheduled activities were conducted due to time constraints and schedule interruption.

Actual: 9, 436 trees grown $(81.07 \%)$

Each of the class sections cultivated their own small vegetable garden near their respective classrooms. The vegetables mostly grown were eggplant, spring onions, tomatoes, chili pepper, lemon grass, 'malunggay', 'monggo', 'alugbati' and 'okra'.

3. Establish seed banks to
sustain seed requirement
for different planting
cycles as well as fruit
bearing and forest tree
saplings for the tree-
planting.
4. Enhance the development of values among learners by integrating curricula concepts in planting and eating vegetables, waste management and environmental protection.

5. Coordinate with other agencies, NGOs, and private institutions relative to the program.

6. Conduct monitoring and evaluation.

The school was not able to establish any nursery or seed bank of any kind of fruit bearing or forest tree.

These values of planting and eating vegetables were mostly discussed in the Health component of MAPEH and cooking lessons in TLE subjects. The values concerning environment were tasked to be integrated by the Science teachers to their lessons.

In every mangrove tree planting activity, the school tapped propagules ready for planting. tagged pictures with the location Congruences / Discrepancies Most of the school personnel, the entire Grade 10 and 11 classes and some from the lower grades were able to grow at least ten trees. Not all target participants were able to join the activity.

Gap: 2, 204 trees $(18.93 \%)$

The harvested vegetables were cooked during the feeding program. Those in excess were sold and the proceeds went to the class sinking fund. However, some vegetable gardens were not maintained well throughout the year.

No seed banks were developed due to non availability of space for them in the school campus. The seedlings planted were just brought by students or provided by the NGO. The value of planting and eating vegetables, waste management and environmental protection were well inculcated to the students through discussions in specific areas.

The school has been closely Simala Bantay Dagat Though, it would have been $(\mathrm{SimBaDa})$ to provide better to tap more NGOs for the program.

Each teacher provided geo- Monthly and quarterly and time where they were taken during the tree planting activity. reports had been submitted regularly to the NGP Division Coordinator. 


\begin{tabular}{l|l|l}
\hline The NGP coordinator then made & $\begin{array}{l}\text { Ramon Aboitiz Foundation } \\
\text { narrative reports supported by } \\
\text { the geo-tagged pictures. She also } \\
\text { Inc. (RAFI) an NGO had } \\
\text { visited the mangrove site to } \\
\text { evaluate what reports for the } \\
\text { 'gulayan sa paaran' with } \\
\text { details of when they were } \\
\text { harvested, the volume harvested, } \\
\text { and how they were utilized. A } \\
\text { comprehensive recognized for its active } \\
\text { evaluation was desired. program }\end{array}$ & $\begin{array}{l}\text { support and participation in } \\
\text { tree growing. This school } \\
\text { achievement calls for an } \\
\text { evaluation to point out the } \\
\text { best practices. }\end{array}$ \\
\hline
\end{tabular}

Table 2 reveals the Component $\mathrm{B}$ of the ABCD model which is about the programs and operations of the National Greening Program as implemented by Simala National High School. The intents were based on the objectives stated on DepEd Order No. 5, s. 2014.

Intent 1. At least ten trees were required to be planted for every student, teacher, and non-teaching personnel. Though, some of the participants were able to plant more than the required number. Based on the year-end report of the School NGP Coordinator, 9, 436 mangrove propagules were grown by the participants for school year 2016-2017 which is $81.07 \%$ of the target. However some of the students and the administrative assistants were not able to participate in any of the tree planting activity due to time constraints. The non-compliance of these students could be attributed on not setting the schedules ahead of time and being not proactive of some schedule interruptions. Examples of these are the October, December, and March schedules in which they were affected by the semester break, Christmas break, and end of the school year respectively. The school should have set ahead the schedule and strictly adhere to it. There should be a back-up plan in case of schedule interruption. Each class section should have been properly assigned too for the students to be guided properly.

Intent 2. Based on the same DepEd Order, propagation of various vegetables that will address micro-nutrient deficiencies is highly encouraged. Studies showed that micro-nutrient supplementation has an effect on the intelligence of children (Benton, 2001). Examples of these deficiencies to be addressed are protein-energy malnutrition, vitamin A deficiency (VAD), iron deficiency anemia (IDA), and iodine deficiency disorder (IDD). Ebert (2014) explained that the essential sources of vitamins, micro-nutrients and protein are the traditional vegetables and underutilized legume crops. Hence, they are valuable factors to attain nutritional security.

Various vegetables were produced throughout the year since each section was required to cultivate a small vegetable garden. Based on the yearend report, the volume harvested of various vegetables were as follows, eggplant - 5 kilos, malunggay - 3 bunches, spring onions - 2 kilos, alugbati - 
5 kilos, tomatoes - 2 kilos, chili pepper - 1 kilo, lemon grass - 1 bunch, monggo - 2 kilos, and okra - 1 kilo. Some of the harvest were utilized for the school feeding program in which 78 students who were identified as undernourished benefited from the nutrients of these vegetables. The school has performed well in this aspect though some of the vegetable gardens were not consistently maintained all throughout the year. Nonetheless, the school was able produce enough vegetables to sustain its feeding program.

Intent 3. DepEd Order No. 5, s. 2014 stated that at least one school in every district will serve as the center for the production of vegetable, fruit bearing tree, and forest tree seedlings to provide the seedling requirements for the tree planting and 'gulayan sa paaralan' activities. Haase \& Davis (2017) stressed that nursery-grown plants of high quality are significant requirements for successfully implementing forest and landscape restoration programs towards sustainable ecosystems.

The school was not identified to be the center of the seedling production due to unavailability of space. Yet, no school was identified in the entire district to serve as the center for this purpose. The school heads led by the district supervisor should have chosen a school which can provide a good area for the nursery. There should be a memorandum from the division office reminding each district about this concern.

Intent 4 . The school head encouraged all the teachers especially those handling MAPEH, TLE, and Science subjects in integrating the significance of planting and eating vegetables, waste management and environmental protection in their lessons. Morris et al (2000) emphasized that school-based gardens of vegetables is an innovative approach in reinforcing nutrition lessons and motivating children to eat healthily.

There was also one time that the teachers received a brief seminar from the personnel of Simala Bantay Dagat (SimBaDa) about Mangrove Tree Planting. The teachers then echoed what they learned to the students. The school has been effective in this aspect since the students manifested desirable behaviors on advocacies concerning the environment.

Intent 5. Simala Bantay Dagat or SimBaDa which is an organization of people living near the sea and recognized by the barangay had been providing the school with mangrove propagules in every tree planting activity. They identified the areas where the mangroves are supposed to be planted in order to have high survival rate by not getting in the way of the fishermen's boats. This evidently showed that the school has been closely coordinating with organizations for the success of its NGP implementation. Austin (2002) related that partnering to local residents in neighborhoods can have positive impacts on the survival of the trees and thus fostering community development. 
Intent 6. The school NGP coordinator had been requiring the teachers to submit geo-tagged pictures of themselves and their students during the tree planting activity. Pictures with real time and location where they were taken assured an honest report from each school during the monitoring and evaluation of the program. Ramon Aboitiz Foundation Inc. (RAFI), a NonGovernment Organization (NGO) in partnership with the Department of Education had an on-site visit of the mangroves planted by the school. They were looking for schools that had an outstanding accomplishment in the Tree Growing program. A plaque of recognition was then awarded to the school last July 04, 2017 as recognition for its active support and outstanding participation in tree growing.

\section{Component C - Effects}

Chen \& Chen (2005) related that the stakeholders expectations should be primarily considered in designing an evaluation. In this part, immediate effects to the participants were identified to determine if it coincide to what is expected from the program. Ten students and ten teachers who had actively participated in the tree planting and 'gulayan sa paaralan' activities were interviewed. Using open ended questions, four themes were generated based on their significant statements in the interviews.

Theme 1. "Points for the Effort" The teachers made it a common understanding to give additional points to the students in various subjects who will participate in the tree planting activity and help maintain the 'gulayan sa paaralan'. It was one way to motivate them to actively join the NGP activities. The teachers were able to get additional points also in their year-end performance rating since it was one of the metrics in their evaluation. The teachers interviewed revealed that one of their motivations to join the activities is to maintain a good performance evaluation rating. These personal effects to the students and teachers were major factors to keep them enthusiastic of this program. A student interviewee remarked: "I really give my effort to our vegetable garden because my teachers would add points to my performance task in MAPEH and TLE subjects."

Theme 2. "Complied as Required" The division memorandum released monthly was issued to remind the schools of the upcoming schedule. It clearly stated that the consolidated quarterly reports on tree or vegetable growing day shall form part of the requirements for moving up of Grade 10 students. The said reports with ten geo-tagged pictures shall also be the required documents for promotion of teachers, school heads, and district supervisors. Hence, Grade 10 students who will be moving up for the school year were prioritized in scheduling the tree planting activity. Teachers who sought promotion too were very compliant of the monthly schedule. As a result, all the Grade 10 students were able to join the moving up ceremony and 
some teachers were eventually promoted. One teacher interviewee said: "It was like hitting two birds with one stone. I was able to help the environment and at the same time I got promoted."

Theme 3. "Green Advocates" One of the objectives of this program is the development of values of planting and eating vegetables, waste management, and environmental protection among the participants. Teachers made sure that the significance of the NGP activities were well integrated in their lessons. Hence, more students were now engaged in vegetable eating because they witnessed that they were grown naturally in front of their classrooms (Morris et al, 2000). A student interviewee said: "I will already eat vegetables because we were the one who planted them and I am sure that no chemicals were applied."

The students were motivated of planting more mangrove trees because they saw their benefits during calamities. A student interviewee who lives near the sea said: "The mangroves were big help during the typhoon because they blocked the big waves towards our house." It is indeed a high time to conserve mangroves in order to stabilize and maintain a healthy coastal environment (Sandilyan \& Kathiresan, 2012).

Theme 4. "Environmental Champions" The students and teachers have felt self-fulfillment after the tree planting activity. They thought they have done something good to the environment that can be very beneficial to everyone. A student interviewee said: "It is such a nice feeling planting a lot of mangroves today because only few like to do this for they may find this task very tiresome." The students felt the same sense of fulfillment when they saw the vegetables they have grown were harvested and cooked for the feeding program. They were even excited planting the next round of vegetables in their garden. The teachers were also glad too that they were engaged in this kind of activity because they thought that its part of their role to become models who care for the environment. A teacher interviewee said: "We are glad of this opportunity of planting mangrove trees because the students looked up at us and seeing that we do this kind of activity would encourage them of doing the same."

\section{Component D - Social Impact}

Eight residents living in the area were interviewed about the benefits they have gained from the mangroves planted. Ten parents of the identified undernourished students who were subjected to the supplementary feeding program were interviewed about how the 'gulayan sa paaralan' activity helped their children.

Theme 1. "Disaster Mitigation" It has been the initiative of one of the teachers in school to plant mangroves in compliance with the NGP. The school's advocacy to mangrove planting was ignited by the devastating effects 
of typhoon "Seniang" last December, 2014 where the houses in the seashore were damaged due to storm surge. A lot of students lost their houses and there was even a donation drive done in school for the victims. The barangay has been very supportive of this endeavor because they knew that the more mangroves planted, the more residents will be protected. So in partnership with SimBaDa, the school consistently advocates the mangroves for its tree planting schedule. In fact, all six tree planting activities conducted for school year 2016-2017 were undertaken in the mangrove planting sites. The mangroves have now proven its benefits as it help mitigate the effects of storm surge during typhoons (Das \& Crépin, 2013). A resident interviewee said: "For the past typhoons, we have noticed that the storm surge was not as strong as before because a lot of mangroves are holding them back."

The students who were greatly affected by the typhoon "Seniang" were also the one very active in planting the mangrove propagules. Another resident interviewee who is also a parent of one of the students said: "We are very happy that you chose our place as the site for mangrove planting. My children were also victims of the typhoon and I really encouraged them to plant more mangroves because these are for their own good too."

Theme 2. "Fighting Malnutrition" Every class adviser was required to report the nutritional status of his/her advisory class in the beginning of the school year. This was to identify the undernourished students who will be subjected to the supplementary feeding program. Out of more than a thousand students of the school, 78 were identified to be undernourished with lower than normal BMI index. Thus throughout the year, these students were fed at least once a month by nutritious food in which the main ingredients were the vegetables harvested in school. The vegetables produced were grown naturally by the students to fight micro-nutrient deficiency as part of the 'gulayan sa paaralan' program (Inocian \& Nuneza, 2015).

The year-end report of the students' nutritional status revealed that only 22 out of 78 students remained undernourished after the monthly feeding program. This improvement could be attributed to the healthy vegetables which can be accessed for free. A parent interviewee said: "The vegetables they have eaten cooked by the teachers in school help them gain weight and be more active in the household chores. " The parents of the undernourished students who were made aware of their children's nutritional status were delighted of the schools support in fighting malnutrition through naturally grown vegetables. They were inspired to do the same in their residences. A parent interviewee said: "These vegetables eaten by my child is surely natural because they are produced in school. We are inspired to grow vegetables at home so that my child will gain more weight and have more energy." Thus, school-based vegetable gardens can teach students healthier eating habits and eventually lessen malnutrition (Morris, 2000). 
Clearly, the National Greening Program has a significant impact to the society especially in disaster mitigation and fighting malnutrition.

\section{Conclusion and Recommendations}

Based on the foregoing results and findings, the researcher concluded that the implementation of the National Greening Program in Simala National High School for the school year 2016-2017 has been effective based on the evaluation done utilizing the ABCD model. The intents among the four components evaluated namely participants, programs and operations, effect, and social impact coincide with the actualities with only minor discrepancies.

The following recommendations are presented by the study: (1) The school may set the monthly schedules of tree planting ahead of time with back up plan for any interruptions and assign specific classes for each schedule in order to involve all the target participants; (2) Non-teaching personnel shall be required to participate in the activities and teaching personnel shall be encouraged to attend every schedule since their attendance is required for promotion purposes; (3) The school head shall coordinate with the supervisor in identifying a school in the district which will be the center for the seedling production; (4) The school shall coordinate with more government agencies and non-government organizations to widen the coverage of NGP implementation.

\section{References:}

1. Akomolafe, C. O., \& Adesua, V. O. (2019). An Evaluative Study on the Accreditation of Academic Programmes and Quality Assurance in Public Universities in Nigeria. European Scientific Journal, ESJ, 15(4), 40.

2. Aquino, A. P., \& Daquio, C. R. O. (2014). Executive order no. 26: towards a greener Philippines. Policy Paper, Food and Fertilzer Technology Center, Taipei, Taiwan, 10.

3. Austin, M. E. (2002). Partnership opportunities in neighborhood tree planting initiatives: Building from local knowledge. Journal of Arboriculture, 28(4), 178-186.

4. Balangue, T. O. (2016). National Greening Program assessment project: environmental component-process evaluation phase (No. 2016-11). PIDS Discussion Paper Series.

5. Benton, D. (2001). Micro-nutrient supplementation and the intelligence of children. Neuroscience \& Biobehavioral Reviews, 25(4), 297-309.

6. Chen, H. T., \& Chen, H. T. (2005). Practical program evaluation: Assessing and improving planning, implementation, and effectiveness. Sage. 
7. Das, S., \& Crépin, A. S. (2013). Mangroves can provide protection against wind damage during storms. Estuarine, Coastal and Shelf Science, 134, 98-107.

8. DepEd Memorandum No. 58-2011. (March 11, 2011), retrieved from http://ngp.denr.gov.ph/index.php/referencematerials/issuance

9. DepEd Memorandum No. 5-2014. (February 07, 2014), retrieved from http://www.deped.gov.ph/

10. Ebert, A. (2014). Potential of underutilized traditional vegetables and legume crops to contribute to food and nutritional security, income and more sustainable production systems. Sustainability, 6(1), 319-335.

11. Executive Order No. 23, s. 2011.( February 1, 2011), retrieved from http://www.gov.ph/2011/02/01/executive-order-no-23-4/

12. Executive Order No. 26, s. 2011 (February 24, 2011), retrieved from http://www.gov.ph/2011/02/24/executive-order-no-26-2/

13. Garen, E. J., Saltonstall, K., Slusser, J. L., Mathias, S., Ashton, M. S., \& Hall, J. S. (2009). An evaluation of farmers' experiences planting native trees in rural Panama: implications for reforestation with native species in agricultural landscapes. Agroforestry Systems, 76(1), 219236.

14. Haase, D. L., \& Davis, A. S. (2017). Developing and supporting quality nursery facilities and staff are necessary to meet global forest and landscape restoration needs. Reforesta, (4), 69-93.

15. Inocian, R. B., \& Nuneza, L. M. (2015). The "gulayan sa paaralan"(school vegetable garden) in response to sustainable development. European Scientific Journal, ESJ, 11(8).

16. Israel, D. C. (2016). Taking stock of the National Greening Program six years hence.

17. Lachica, M. A. P. (2014). Philippines: degraded forest rehabilitation and sustainable forest management in The Philippines. Reports provided by participants, 80 .

18. Luna, M. P. G. (2016). Impact Assessment of the National Greening Program of the DENR: Scoping or Process Evaluation PhaseInstitutional Component (No. 2016-29). PIDS Discussion Paper Series.

19. Mangarun, A. J. S. (2014). Evaluation of the MSU-IIT College of Nursing Enhancement Program Using the ABCD Model As a Framework. CNU Journal of Higher Education, 8, 90-103.

20. Mehrafsha, S. J. (2011). A Proposed Blueprint Model towards the Evaluation of Educational System in Iran. World Journal of Education, 1(1), 72-80.

21. Merriam, S. B., \& Tisdell, E. J. (2015). Qualitative research: A guide to design and implementation. John Wiley \& Sons. 
22. Morris, J., Briggs, M., \& Zidenberg-Cherr, S. (2000). School-based gardens can teach kids healthier eating habits. California Agriculture, 54(5), 40-46.

23. Morrow, R., Rodriguez, A., \& King, N. (2015). Colaizzi's descriptive phenomenological method. The psychologist, 28(8), 643-644.

24. Nava, L. H., Ochave, J. A., Romero, R. C., Ruscoe, R. B., \& Mabunga, R. A. S. (2007). Evaluation of the UNESCO-Associated Schools Project Network (ASPNet) in Teacher Education Institutions in the Philippines. The Normal Lights, 1(1).

25. Sandilyan, S., \& Kathiresan, K. (2012). Mangrove conservation: a global perspective. Biodiversity and Conservation, 21(14), 35233542.

26. Sarker, P. K., \& Rodrigo, R. (2014). A review of the Status and Trends of Forest Cover in Bangladesh and Philippines. In Proceedings of the 4th International DAAD Workshop on "The Ecological and Economic Challenges of Managing Forested Landscape in a Global Context" from (Vol. 16).

27. Shosha, G. A. (2012). Employment of Colaizzi's strategy in descriptive phenomenology: A reflection of a researcher. European Scientific Journal, ESJ, 8(27).

28. Toili, W. W. (2007). Secondary School Students' Partipation in Environmental Action: Coercion or Dynamism?. Eurasia Journal of Mathematics, Science \& Technology Education, 3(1).

29. United Nations, \& United Nations Conference on Environment and Development (1992: Rio de Janeiro, Brazil). (1993). Agenda 21: Programme of Action for Sustainable Development: Rio Declaration on Environment and Development: Statement of Forest Principles. New York: United Nations.

30. Walters, B. B. (2000). Local mangrove planting in the Philippines: are fisherfolk and fishpond owners effective restorationists?. Restoration Ecology, 8(3), 237-246.

31. Zubair, M., \& Garforth, C. (2006). Farm level tree planting in Pakistan: the role of farmers' perceptions and attitudes. Agroforestry systems, 66(3), 217-229. 